\title{
Nutritional Intervention as an Essential Part of Multiple Sclerosis Treatment?
}

\author{
A. PENESOVÁ ${ }^{1,4}$, Z. DEAN ${ }^{1,2}$, B. KOLLÁR ${ }^{3}$, A. HAVRANOVÁ ${ }^{1}$, R. IMRICH ${ }^{1}$, \\ M. VLČEK ${ }^{1,4}, \check{Z}$. RÁDIKOVÁ ${ }^{1,4}$ \\ ${ }^{1}$ Institute of Clinical and Translational Research, Biomedical Research Center of the Slovak \\ Academy of Sciences, Bratislava, Slovakia, ${ }^{2}$ Department of Neurology, Faculty Hospital, Nitra, \\ Slovakia, ${ }^{3}$ First Department of Neurology, Faculty of Medicine, Comenius University, Bratislava, \\ Slovakia, ${ }^{4}$ Slovak Medical University in Bratislava, Bratislava, Slovakia
}

Received June 21, 2017

Accepted February 2, 2018

On-line May 10, 2018

\section{Summary}

Multiple sclerosis (MS) is a chronic inflammatory and demyelinating disease of the central nervous system. In addition to the genetic, epigenetic and immunological components, various other factors, e.g. unhealthy dietary habits, play a role in the MS pathogenesis. Dietary intervention is a highly appealing approach, as it presents a simple and relatively low risk method to potentially improve outcomes in patients with brain disorders in order to achieve remission and improvement of clinical status, well-being and life expectancy of patients with MS. The importance of saturated fat intake restriction for the clinical status improvement of MS patients was pointed for the first time in 1950s. Recently, decreased risk of first clinical diagnosis of CNS demyelination associated with higher intake of omega-3 polyunsaturated fatty acids particularly originating from fish was reported. Only few clinical trials have been performed to address the question of the role of dietary intervention, such is e.g. low saturated fat diet in MS treatment. This review summarizes current knowledge about the effect of different dietary approaches (diets low in saturated fat and dietary supplements such as fish oil, lipoic acid, omega-3 polyunsaturated fatty acids, seeds oils, high fiber diet, vitamin $\mathrm{D}$, etc.) on neurological signs, patient's well-being, physical and inflammatory status. So far the results are not conclusive, therefore much more research is needed to confirm and to understand the effectiveness of these dietary interventions in the long term and well defined studies.

\section{Key words}

Multiple sclerosis • Neuroinflammation • Diet • Saturated fatty acids $\bullet$ Unsaturated fatty acids

\section{Corresponding author}

A. Penesová, Institute of Clinical and Translational Research, Biomedical Research Center of the Slovak Academy of Sciences, Dúbravská cesta 9, 84505 Bratislava, Slovakia. E-mail: adela.penesova@savba.sk

\section{Introduction}

Multiple sclerosis (MS) is a chronic immunemediated inflammatory disease affecting the central nervous system (CNS), leading to neurodegenerative processes in the nervous system, characterized by inflammation and myelin loss. The disease typically manifests as motor impairment, visual disturbances, or sensory problems. Other symptoms include, pain, fatigue and cognitive impairment (Dendrou et al. 2015). MS usually develops in young adults; women are more likely to be affected. There are two main types of the disease: 1) relapsing-remitting MS (85\%) with inflammation and demyelination as the primary pathology and 2) primaryprogressive MS (15\%) with neurodegeneration - axonal degeneration as the primary pathology (Storoni and Plant 2015). 
The prevalence of MS is higher in developed countries (Evans et al. 2013); the highest in the Orkney Islands, which belong to Scotland (250 per 100,000), Norway (208 per 100,000 in 2013; the reported prevalence of MS in Norway has increased 10-fold during last 8-9 decades) (Grytten et al. 2015), followed by Hungary (176 per 100,000), Slovenia (150 per 100,000), Germany (149 per 100,000), USA (135 per 100,000), Canada (149 per 100,000), and Czech Republic (130 per 100,000). MS is very common in Scandinavia, northern and middle Europe (80-100 per 100,000), extremely rare in Japan (2 per 100,000) and is almost unknown in the Indian subcontinent (Browne et al. 2014, Kingwell et al. 2013).

The pathogenesis of MS is complex and multifactorial (Wu et al. 2016). In addition to the genetic, epigenetic and immunological components, various other environmental factors may play a role in the development of MS (brain injury, viral infection, i.e. Epstein-Barr virus, nutrition - so-called Western diet, physical inactivity, obesity in childhood and adolescence, smoking, low vitaminD level, etc.) (Dos Passos et al. 2016, Pierrot-Deseilligny and Souberbielle 2017). On the other hand, physical exercise, assumed ,healthy diet“" and restoration of optimal concentrations of vitamin D have an antiinflammatory effect and may ameliorate the course of many chronic inflammatory diseases, such as MS (Marck et al. 2016). Meta-analysis of epidemiological studies has demonstrated a relation between MS mortality and dietary fat, where intake of saturated fatty acids, mainly in animal fat products, correlates positively with MS mortality (Esparza et al. 1995). An increased risk of MS was found to be associated with high energy and animal food intake (Ghadirian et al. 1998). The same study also revealed a protective effect of other nutrients, including vegetable protein, dietary fiber, cereal fiber, vitamin $\mathrm{C}$, thiamine, riboflavin, calcium and potassium. In contrast, another study found no associations between intake of fruits and vegetables, multivitamins, vitamins $\mathrm{C}$ and $\mathrm{E}$, and the risk of MS in women (Zhang et al. 2001).

It is known that the so-called Western diet contains, besides others, too much fat, especially saturated fatty acids (SAFA). Data from Food and Agriculture Organization of the United Nations indicate that during the last 30 years fat from all sources consumed by Americans increased from $119 \mathrm{~g}$ per capita per day to $155 \mathrm{~g}$ per capita per day ( $85 \mathrm{~g}$ from monounsaturated fats (MUFA)), representing $42 \%$ of total energy intake. Further findings reported that the US dietary pattern changed, including more saturated fats as a result of broad availability of fast foods (WilczynskaKwiatek et al. 2010). In French adults the mean total fat intake per capita per day was $94.1 \mathrm{~g}$ in men $(36.3 \%$ of total energy intake) and $73.4 \mathrm{~g}$ in women (38.1\%), respectively (Astorg et al. 2004).

The current recommended dietary allowance for fat intake for adults varies from 20 to $35 \%$ of total daily calories according to the World Health Organization, Food and Agriculture Organization of the United Nations, the European Food Safety Authority or dietary guidelines for Americans. Intake of SAFAs should not exceed $10 \%$ of total daily caloric intake. The recommended range for polyunsaturated fatty acids (PUFAs) is 6-11\% of total daily caloric intake (FAO 2010) (Table 1).

Table 1. The recommended fat intake for adults (FAO 2010).

\begin{tabular}{lccc}
\hline Diet & Total fat/day & SAFAs/day & PUFAs/day \\
\hline $\begin{array}{l}\text { 2000 } \\
k c a l / d a y\end{array}$ & $44-78 \mathrm{~g}$ & $<22 \mathrm{~g}$ & $13-24 \mathrm{~g}$ \\
$\begin{array}{l}2500 \\
k c a l / d a y\end{array}$ & $56-97 \mathrm{~g}$ & $<28 \mathrm{~g}$ & $17-31 \mathrm{~g}$ \\
\hline
\end{tabular}

On the other hand, south Asian diet (India, Korea, Thailand, etc.) is low in SAFAs and high in PUFAs (especially omega-6), and Japanese consume large amounts of omega-3 fatty acids, mostly from sea food. Other contributing factor is high intake of vegetables and lots of plant food rich in dietary fibers. Therefore, the question arises, whether these dietary habits can explain the rare prevalence of MS in these populations, besides the genetic and epigenetic factors.

Lot of patients with MS use special diet and dietary supplements proposed by complementary and alternative medicine, mainly due to unsatisfactory effect of the conventional therapy or its side effects.

\section{Fat intake and neuro-inflammation}

Myelin around axons, its lipid composition, and membrane lipid morphology are affected during the progression of neuroinflammatory and neurodegenerative diseases. High fat diet induces markers of brain inflammation, with proinflammatory actions in cerebral cortex and hippocampus.

Cholesterol is an essential component of cellular 
and myelin membranes of neuronal cells in mammals. In a comprehensive review (Zhornitsky et al. 2016), the relationship between levels of cholesterol and markers of cholesterol turnover in circulation and/or cerebrospinal fluid and MS outcomes was discussed. It was suggested that cholesterol and related molecules might be potentially used as markers of the disease activity, of the treatment efficacy or as a new therapeutic target. Increased levels of circulating total cholesterol, LDL-cholesterol, apolipoprotein B and oxidized LDL are associated with adverse disease outcomes. Since the metabolic and vascular comorbidities, such as atherosclerosis, hypertension and obesity, including hypercholesterolemia, are associated with increased risk of developing MS and its rapid progression, the causal relationship between high cholesterol levels and MS outcomes needs to be elucidated (Zhornitsky et al. 2016).

Increased intake of certain SAFAs and linoleic acid (LA, 18:2, n-6), introduction of industrially produced trans fatty acids into food chain, and reduced intake of omega-3 fatty acids (notably alpha-linolenic acid (18:3, n-3) from vegetable sources) might have adverse health effects (Blondeau et al. 2015, FAO 2010, Sala-Vila et al. 2016). Omega-3 fatty acids are a family of PUFAs, the parent omega- 3 fatty acid is 'the essential fatty acid', the alpha-linolenic acid (18:3, n-3), which must be supplied by diet and can be found in nuts and seeds - flax, hemp, poppy, soybean and their oils. The source of omega-3 fatty acids, eicosapentaenoic acid (EPA, 20:5, n-3) and docosahexaenoic acid (DHA, 22:6, $\mathrm{n}-3$ ) is fish (e.g. salmon, mackerel, herring and sardine), their synthesis from alpha-linolenic acid in humans is limited (Fetterman and Zdanowicz 2009). DHA crosses the blood-brain barrier and, along with arachidonic acid, is a major component of neuronal cell membranes (Lim and Suzuki 2000). EPA can be converted to prostaglandin I3 and E3, thromboxane A3 and leukotriene B5, and therefore has immunomodulatory capacity, acting as an anti-inflammatory agent (Calder 2002, Fetterman and Zdanowicz 2009). PUFAs (in particular DHA and EPA) have neuroprotective action (Das 2001b, Das 2002, Lauritzen et al. 2000) and inhibit the production of IL-1, IL-2, and TNF (Kumar and Das 1994, Kumar et al. 1992). Finally, both EPA and DHA can form new antiinflammatory bioactive molecules, called resolvins, protectins, and maresins, which are able to reduce cellular inflammation and inflammatory pain (Hong and Lu 2013, Serhan et al. 2015, Xu et al. 2010). DHA is present at high concentration in the brain and its level decreases dramatically in MS patients (Nightingale et al. 1990). On the basis of its anti-inflammatory and neuroprotective action, fish oil supplementation was found to be highly effective in reducing the levels of cytokines and nitric oxide in patients with relapsing-remitting MS under treatment with IFN- $\beta$ (Ramirez-Ramirez et al. 2013).

Further, n-3 fatty acids (especially EPA and DHA) enhance the production of transforming growth factor- $\beta$ (TGF- $\beta$ ), which shows anti-inflammatory properties (Das 1993, Das 1995, Fernandes et al. 1998, Newman 1990). In chronic silent MS, TGF- $\beta$ transcription was reported to be increased, reflecting gliosis or suppression of the inflammatory response (Lock et al. 2002).

Lipoic acid (containing sulphur) is an antioxidant and therefore important for normal function of mitochondria. It has been shown to be an effective treatment for animal model of MS - the experimental autoimmune encephalomyelitis (EAE) (Marracci et al. 2002, Morini et al. 2004, Schreibelt et al. 2006). Lipoic acid suppresses EAE by interfering with trafficking of encephalitogenic $\mathrm{T}$ cells into the spinal cord. Lipoic acid has immunomodulatory and antiinflammatory properties, stabilizes the integrity of the blood-brain barrier (BBB) and stimulates the production of cAMP and the activity of protein kinase A (Salinthone et al. 2010). Immunomodulatory effects of lipoic acid involve several mechanisms, e.g. inhibition of the expression of the intercellular and vascular cell adhesion molecules (ICAM-1 and VCAM-1) by CNS endothelial cells (Marracci et al. 2002, Marracci et al. 2004, Morini et al. 2004). Lipoic acid is a nutritional supplement with a variety of biological effects as antioxidant and is approved for treatment of peripheral neuropathy (Ziegler et al. 1999).

Neuronal cells represent insulin independent tissue in terms of using glucose as a fuel; however, brain is rich in insulin receptors (Hill et al. 1986). Insulin has many functions in the brain; insulin itself participates in neuronal growth and differentiation, neurotransmitter release, and synaptic plasticity (Bruning et al. 2000, Rulifson et al. 2002). SAFAs can make the cell membrane rigid, reduce the number of insulin receptors and the affinity of insulin to its receptors. So, an important function of PUFAs in the brain is to ensure the presence of adequate number of receptors for insulin and neurotransmitters for their appropriate actions. Moreover, insulin enhances the activities of desaturases (Das 2005, Das 2007) and thus increases the formation of 
n-6 and n-3 long-chain PUFAs from their respective precursors. Insulin stimulates the endothelial nitric oxide (eNO) synthesis (Kuboki et al. 2000), modulates immune response, and has anti-inflammatory actions (Das 2001a, Sun et al. 2014). Balance between PUFAs and SAFAs in the cell membrane is critical to the function of insulin (Das 1994). Appropriate amounts of PUFAs and, consequently, insulin receptors in the brain are critical to the health of brain neurons. Thus, when adequate amounts of PUFAs (especially DHA) are incorporated into the neuronal cell membranes, it may protect neurons from the cytotoxic action of TNF by its direct neuroprotective action and its enhancement of the number of insulin receptors because insulin can silence the neurotoxic signal of TNF. Recently, epidemiological studies on neurodegenerative disorders have evaluated the beneficial effect of PUFAs on multiple sclerosis (Wergeland et al. 2012).

In our previous study (Penesova et al. 2015), we found signs of insulin resistance in newly diagnosed, untreated patients with MS with low Expanded Disability Status Scale (EDSS) score (1.1 \pm 0.7$)$. Our data further suggest that chronic inflammation, physical inactivity, autonomous nervous system dysfunction, changes in incretin or adipokine secretion are not likely to be involved in the development of insulin resistance in MS patients. Gong et al. (2008) hypothesized that in vivo insulin deficiency may be a novel etiological cause of demyelinating disease and thus improving the insulin sensitivity represents the novel therapeutical strategy for remyelination and neuronal repair. There are few running studies with peroxisomal proliferators-activated receptor gamma (PPAR- $\gamma$ ) agonists (a common antidiabetic drug) in MS (Bright et al. 2008). However future human trials will probably confirm the safety and efficacy of PPAR agonists for MS treatment.

Hoare et al. (2016) examined the association between usual fat intake (total, SAFA, MUFA, PUFA, omega-3 and omega-6) and risk of a first clinical diagnosis of CNS demyelination (FCD) in a multi-center incident case-control study in four regions of Australia during 2003-2006. Dietary data were collected from patients with FCD and matched controls using a validated food frequency questionnaire. They found that there was a significant decrease in FCD risk with higher intake of omega-3 PUFA, particularly that from fish sources. There was no evidence to indicate that the intake of other types of dietary fat or fat quantity in the 12 months prior diagnosis was associated with an altered risk of FCD.
In a double-blind and randomized study, no differences were observed between MS patients and healthy controls with regard to fat malabsorption (Wong et al. 1993). Nevertheless, there were deficiencies of essential PUFAs (i.e. PUFAs of the $n-3$ and n- 6 series) in both plasma lipids and erythrocytes of MS patients (Cunnane et al. 1989, Holman et al. 1989, Cherayil 1984). Plasma LA (18:2, n-6) was normal, gammalinolenic acid (18:3, n-6) was increased in MS patients, but subsequent n-6 acids were subnormal, indicating impairment of chain elongation (Holman et al. 1989). In addition, the content of all n-3 fatty acids was subnormal and PUFA deficiency was compensated mass-wise by an increase in saturated fatty acids concentrations in plasma. Fatty acids levels in red blood cells and adipose tissue change more slowly and persist longer than in serum, and therefore relate more likely to long-term changes in fatty acids levels or metabolism, rather than reflecting dietary alterations. In red blood cells of mild inactive MS patients, there was a significant reduction in EPA (20:5, n-3), and an increase in dihomo-gammalinolenic acid (20:3, n-6) and stearidonic acid (18:4, n-3) (Nightingale et al. 1990). No detectable EPA levels in the adipose tissue of MS patients and healthy individuals could be observed. However, whereas in MS patients DHA (22:6, n-3) was not detectable, $40 \%$ of healthy controls had significant levels. No reduction in LA was observed in red blood cells or adipose tissue of MS patients (Nightingale et al. 1990). In MS plaques, the lipid and fatty acid composition appears to be altered (Wilson and Tocher 1991). The cause of these PUFA deficiencies is not entirely clear and may involve metabolic and nutritional alterations. Long chain n-3 fatty acids such as EPA and DHA are important in the development of the central nervous system, have antiinflammatory and neuroprotective effects and their decreased levels may be relevant to the pathogenesis and treatment of MS.

\section{The role of dietary habits in neuro- degeneration}

Dietary habits and especially intake of fatty acids have been suggested as a possible environmental factor affecting risk and progression of MS. First studies on the effect of dietary fat on MS risk from 1950 (Swank 1950) attributed higher incidence of MS in inland farming communities compared to coastal regions of Norway to dietary habits (high content of animal and dairy saturated 
fat in inland and higher content of fish on the coast).

Based on this observation, a diet with a very low intake of SAFAs for patients with MS was proposed (Swank 1950). Restricting saturated fat intake induced remission and improvement of the disease and showed a marked beneficial effect on the well-being and lifeexpectancy of patients with MS (Swank 1950, Swank and Dugan 1990, Swank and Goodwin 2003a, Swank and Goodwin 2003b). Patients with actual saturated fat intake of $<20 \mathrm{~g}$ per day were almost free of MS and showed fewer deaths that could be attributed to MS compared with much worse prognosis in those who consumed $>20 \mathrm{~g}$ of saturated fat per day.

Mounting evidence indicates that nutrition can play an important role in MS, however the MS therapy is not currently combined with any dietary and/or lifestyle recommendations.

There have been a number of studies reporting the prevalence of complementary and alternative medicine (CAM) use by MS patients, with a quite broad range of 33-70\% (Berkman et al. 1999, Leong et al. 2009, Marrie et al. 2003, Nayak et al. 2003, Page et al. 2003, Schwartz et al. 1999, Schwarz et al. 2008, Stuifbergen and Harrison 2003, Yadav et al. 2006, Masullo et al. 2015). The most prevalent types of CAM are vitamins/minerals, non-vitamin and non-mineral natural products, relaxation techniques, and special diet. Regarding diet, the median percent of calories from fat $(37 \%)$ and saturated fat $(12 \%)$ were higher than current recommendations, while dietary fiber intake met only $87 \%$ of the adequate intake (Masullo et al. 2015). Inadequate intake of certain vitamins and minerals by those following the Swank and Paleo diet suggests that these diets may be too restrictive, thus further research is needed. A revival of interest among MS researchers for the therapeutic potential of the CAM therapies (diet, omega-3 fatty acids and antioxidants was reported (Yadav et al. 2010b).

The effect of PUFA supplementation in MS has been extensively investigated, but with equivocal outcome. Recently, meta-analyses of epidemiological studies (Farinotti et al. 2012, Kong-Gonzalez et al. 2015) evaluated the benefits of dietary supplementation with PUFAs, especially omega-3 fatty acids, in relation to inflammatory, autoimmune and neurodegenerative disorders. The results (based on insufficient data and design limitations) were ambiguous, suggesting some evidence of a protective effect of PUFAs in MS, with a tendency to reduce the frequency of relapses, however without a major effect on MS progression.

The evaluation of three double-blind trials with LA (18:2, n-6) in early MS showed reduction of increase in disability, severity and duration of relapses (Dworkin et al. 1984). Fish oil supplemented together with vitamins and dietary counseling improved the clinical outcome in newly diagnosed MS patients (Nordvik et al. 2000). On the other hand, a clinical trial with n-3 PUFA treatment in acute relapsing MS showed no significant differences (Bates et al. 1989). However, there was a favorable trend of the n-3 PUFAs-treated group on parameters like overall deterioration, as well as the frequency, severity and duration of relapses. The discrepancies between these studies may be explained by different criteria for patient selection (clinical subtype of MS), and different disability scores at the start of the study (Gallai et al. 1992).

The nutritional studies were focused on the administration of dietary supplements (Farinotti et al. 2012) or on the assignment of diets low in saturated fat, either without supplements (Swank and Goodwin 2003a) or combined with omega-3 fatty acids supplements (Nordvik et al. 2000, Weinstock-Guttman et al. 2005). Other clinical trials were based only on the administration of single dietary supplements such as vitamin D (several, mostly ongoing studies), fish oil (n-3 PUFAs; RamirezRamirez et al. 2013, Shinto et al. 2009) or lipoic acid (Yadav et al. 2010a). In a study evaluating the combined effect of a calorie-restricted, semi-vegetarian diet and administration of vitamin $\mathrm{D}$ and other dietary supplements (fish oil, lipoic acid, omega-3 PUFAs, resveratrol and multivitamin complex) in MS patients for 6 months, the investigators (Riccio et al. 2016) found no significant changes in neurological signs. However, serum levels of the activated isoforms of gelatinase matrix metalloproteinase-9 (a marker of the inflammatory status of the patient) decreased by more than $50 \%$ in MS patients.

Dietary supplementation of patients with relapsing remitting MS with hemp seed oil ( $\sim 55 \%$ linoleic acid (18:2, n-6), $20 \% \alpha$-linolenic acid (18:3, $\mathrm{n}-3)$ ) and evening primrose oil ( $75 \%$ linoleic acid (18:2, $\mathrm{n}-6), \sim 10 \% \gamma$-linolenic acid $(18: 3, \mathrm{n}-6))$ for 6 months achieved significant improvement in EDSS (RezapourFirouzi et al. 2015).

Another study (Bates et al. 1989) reported a trend in improvement of disease severity measured by EDSS in a group of MS patients supplemented with EPA and DHA (from fish oil) when compared to the placebo group receiving oleic acid (from olive oil). The results 
did not achieve statistical significance favoring omega-3 fatty acids supplementation, probably due to the not so optimal study design, because both study groups were advised to follow a diet low in animal fat and high in omega-6 PUFAs. Importantly, both groups developed changes in serum fatty acids levels over the 2 years of the study, which may indicate a diet effect in the placebo group as well.

A similar study with EPA and DHA supplementation together with a diet low in animal fat and high in n-6 PUFAs was conducted in MS patients and matched healthy controls (Gallai et al. 1995). A significant decrease of the proinflammatory cytokines (IL-1 $\beta$, TNF- $\alpha$ and IL-2) as well as proinflammatory eikosanoids (prostaglandin E2 and leukotriene B4) secreted from peripheral blood mononuclear cells of MS subjects and healthy controls was observed after 6 months of supplementation, supporting the suggestion of immunomodulatory effect of n-3 PUFA supplementation.

Recent analysis (Riemann-Lorenz et al. 2016) revealed that patients with MS significantly more often adhered to a "Mediterranean diet" than controls. More than $1 / 3$ of the MS patients had tried special MS diets.

It is known that sunnier, lower-latitude region has lower MS prevalence, than high-latitude region with less solar radiation. Vitamin $\mathrm{D}$, which produced by the action of ultraviolet B rays in the skin, has beyond its role in calcium homeostasis and bone health, immunomodulatory effects and reduces markers of oxidative stress (Dankers et al. 2017, Pierrot-Deseilligny and Souberbielle 2017). Majority of MS patients has vitamin D deficiency, showing seasonal variation. There is an inverse association of serum levels of vitamin D and the seasonal risk of MS relapse (Hartl et al. 2017). Although studies in experimental autoimmune models strongly suggest the protective role of vitamin D in human autoimmune diseases (Dankers et al. 2017), the results of vitamin D supplementation in MS patients were rather inconsistent. There were both positive (Burton et al. 2010, Soilu-Hänninen et al. 2012) and no-effect (Kampman et al. 2012, James et al. 2013) results for disease outcomes, such as EDSS, MRI lesions, functionality, and relapse rates. Safety data suggests that high dose vitaminD is well tolerated and associated with minimal risk.

A low animal fat diet, omega-3 PUFA, lipoic acid and vitamin D supplementation as potential antiinflammatory and neuroprotective agents in both relapsing and progressive form of MS are probably the most promising CAM therapies that warrant further investigation. The positive effects for the MS patient consist in less deterioration, lower relapse rate and reduced severity and duration of relapses.

\section{High fiber diets, gut microbiota and CNS function}

High fiber diets have numerous reported health benefits in reducing risk of obesity, type 2 diabetes, colon cancer, stroke, and cardiovascular diseases, making it a widely recommended healthy diet. CNS and gut are connected through enteric nervous system, autonomic nervous system, immune system, or the metabolic processes of gut microorganisms (microbiota). Many of the reported diet-linked beneficial effects have been associated with the microbiome and its ability to produce short-chain fatty acids (SCFA), like butyrate. Part of the short-chain fatty acids, produced during the colonic fermentation can be absorbed, taken up by the liver and utilized by various tissues (Tarini and Wolever 2010, Wolever and Chiasson 2000). There are many reports of high fiber diets increasing blood levels of circulating butyrate (Priebe et al. 2010, Robertson et al. 2005, Wolever and Chiasson 2000). Some researchers hypothesized the possibility that circulating butyrate could affect CNS function directly. A recent study demonstrated that germ free mice have increased BBB permeability, when compared with specific pathogen free mice containing a healthy microbiota (Braniste et al. 2014). After colonization of the germ free mice with the butyrate-producing bacteria, Clostridium tyrobutyricum, or an oral gavage (for 3 days) of sodium butyrate, BBB permeability restored to the levels of the pathogen free mice. This study demonstrated the strong and important connection between the microbiota, butyrate and the brain. Another study found that mice fed with the soluble fiber diet showed an increase in interleukin 1 receptors $A$, a cytokine and inhibitor of the pro-inflammatory IL-1 $\beta$, in the brain after exposure to the lipopolysaccharide and a decrease in IL-1 $\beta$ and TNF- $\alpha$ (Sherry et al. 2010). Thus, the authors hypothesized that the elevated butyrate from the dietary fiber fermentation may contribute to the immune response. In contrast to the soluble fiber diets, splenocytes from mice on the insoluble fiber diet did not increase IL-4 production when exposed to butyrate in vitro.

Butyrate is a multi-functional molecule that has significant potential as a therapeutic for the brain, both in its pharmacological and dietary form. The source of 
butyrate in a high fiber diet or in a diet rich in natural butyrate is a highly appealing approach, as it presents a simple and relatively low risk method to potentially improve outcomes in patients with brain disorders. However, much more research is needed to understand the effectiveness of these dietary interventions.

Recently, a paper was published about cooperation of commensal microbiota and myelin autoantigen to trigger autoimmune demyelination (Berer et al. 2011). The gut microbiota is composed of trillions of microbes that perform several tasks essential to our physiology. Recent emerging evidences have suggested the important contribution of gut microbiota in several biological functions of mammals, such as the regulation of the immune system, metabolism, intestinal development or brain physiology (Al-Asmakh et al. 2012, Carabotti et al. 2015, Mayer et al. 2015, Petra et al. 2015, Tillisch 2014, Umbrello and Esposito 2016). In fact, recent works, mainly performed in experimental model of MS, have demonstrated that resident commensal microbiota can modulate CNS autoimmunity (Berer et al. 2011, Lee et al. 2011, Ochoa-Reparaz et al. 2009, Yokote et al. 2008). The microbiota is now known to shift the balance between protective and pathogenic immune responses in the CNS and in other organs as well. As regards to CNS physiology, the gut microbiota influences synaptogenesis, regulates neurotransmitters and neurotrophic factors release and function (Diaz Heijtz et al. 2011). A recent study (Miyake et al. 2015) revealed that MS patients have a microbial imbalance (dysbiosis) in their gut microbiota that is most likely linked to the disease pathogenesis. There is growing evidence that gut microbes produce neurotransmitters, such as GABA and serotonin, modulate the immune system, alter epigenetic markers and produce bioactive food components and energy metabolites (Berer et al. 2011, Diaz Heijtz et al. 2011, Hooper 2004). Thus, dietary manipulation to achieve a symbiosis that can improve the health of the microbiome and our brains is an attractive idea currently under investigation. Butyrate, the SAFA produced by colon bacteria, has a role as a potential therapeutics for neurological diseases. The dietary sources of butyrate, either a high fiber diet or a diet rich in natural sources of butyrate, is a highly appealing approach, as it presents a simple and relatively low risk method to potentially improve outcomes in patients with brain disorders. Pharmacologically, butyrate has had a profound beneficial effect on brain disorders ranging from neurodegenerative diseases to psychological disorders
(Bourassa et al. 2016). However, more research is needed to understand the effectiveness of these dietary interventions.

\section{Conclusions}

Dietary intervention is a highly appealing approach to potentially improve outcomes in patients with brain disorders. However, much more research is needed to be confirmed in the long term and well defined studies to understand the effectiveness of these dietary interventions.

Dietary advices represent simple and relatively low risk methods to improve the outcomes in patients with MS, mainly to reduce severity and duration of relapses, to lower relapse rate, to reduce the rate of progression and to decrease the deterioration of the patient. To lower the dietary intake of saturated animal fat is recommended generally, not only for patients with MS. According to the reviewed studies, diet with increased intake of PUFAs, of n-6 group (vegetables, seeds oils), but mainly of n-3 group (EPA and DHA from fish oil), food rich in fiber, supplementation with lipoic acid and vitamin D could have beneficial effect in MS patient.

\section{Conflict of Interest}

There is no conflict of interest.

\section{Acknowledgements}

This work was supported by the Slovak Research and Development Agency (grant number APVV15- 0228 and VEGA grant 2/0161/16, ERA net NEURON II).

\section{Abbreviations}

BBB - blood-brain-barrier, CAM - complementary and alternative medicine, cAMP - cyclic adenosine monophosphate, CNS - central nervous system, DHA docosahexaenoic acid, EAE - experimental autoimmune encephalomyelitis, EDSS - extended disability status score, EPA - eicosapentaenoic acid, FCD - first clinical diagnosis of CNS demyelination, GABA - gamma-aminobutyric acid, ICAM - intercellular adhesion molecule, IFN interferon, IL - interleukin, LA - linoleic acid, LDL - lowdensity lipoprotein, MRI - magnetic resonance imaging, MS - multiple sclerosis, MUFA - monounsaturated fatty acid, PPAR - peroxisomal proliferators-activated receptor, PUFA - polyunsaturated fatty acid, SAFA - saturated fatty acid, SCFA - short-chain fatty acid, TGF- $\beta$ - transforming growth factor $\beta$, TNF - tumor necrosis factor, VCAM vascular cell adhesion molecule. 


\section{References}

AL-ASMAKH M, ANUAR F, ZADJALI F, RAFTER J, PETTERSSON S: Gut microbial communities modulating brain development and function. Gut Microbes 3: 366-373, 2012.

ASTORG P, ARNAULT N, CZERNICHOW S, NOISETTE N, GALAN P, HERCBERG S: Dietary intakes and food sources of n-6 and n-3 PUFA in French adult men and women. Lipids 39: 527-535, 2004.

BATES D, CARTLIDGE NE, FRENCH JM, JACKSON MJ, NIGHTINGALE S, SHAW DA, SMITH S, WOO E, HAWKINS SA, MILLAR JHD, BELIN J, CONROY DM, GILL SK, SIDEY M, SMITH AD, THOMPSON RHS, ZILKHA K, GALE M, SINCLAIR HM: A double-blind controlled trial of long chain n-3 polyunsaturated fatty acids in the treatment of multiple sclerosis. J Neurol Neurosurg Psychiatry 52: 18-22, 1989.

BERER K, MUES M, KOUTROLOS M, RASBI ZA, BOZIKI M, JOHNER C, WEKERLE H, KRISHNAMOORTHY G: Commensal microbiota and myelin autoantigen cooperate to trigger autoimmune demyelination. Nature 479: 538-541, 2011.

BERKMAN CS, PIGNOTTI MG, CAVALLO PF, HOLLAND NJ: Use of alternative treatments by people with multiple sclerosis. Neurorehabil Neural Repair 13: 243-254, 1999.

BLONDEAU N, LIPSKY RH, BOUROUROU M, DUNCAN MW, GORELICK PB, MARINI AM: Alpha-linolenic acid: an omega-3 fatty acid with neuroprotective properties-ready for use in the stroke clinic? Biomed Res Int 2015: 519830, 2015.

BOURASSA MW, ALIM I, BULTMAN SJ, RATAN RR: Butyrate, neuroepigenetics and the gut microbiome: can a high fiber diet improve brain health? Neurosci Lett 625: 56-63, 2016.

BRANISTE V, AL-ASMAKH M, KOWAL C, ANUAR F, ABBASPOUR A, TOTH M, KORECKA A, BAKOCEVIC N, NG LG, KUNDU P, GULYAS B, HALLDIN C, HULTENBY K, NILSSON H, HEBERT H, VOLPE BT, DIAMOND B, PETTERSSON S: The gut microbiota influences blood-brain barrier permeability in mice. Sci Transl Med 6: 263ra158, 2014.

BRIGHT JJ, WALLINE CC, KANAKASABAI S, CHAKRABORTY S: Targeting PPAR as a therapy to treat multiple sclerosis. Expert Opin Ther Targets 12: 1565-1575, 2008.

BROWNE P, CHANDRARATNA D, ANGOOD C, TREMLETT H, BAKER C, TAYLOR BV, THOMPSON AJ: Atlas of Multiple Sclerosis 2013: A growing global problem with widespread inequity. Neurology 83: 1022-1024, 2014.

BRUNING JC, GAUTAM D, BURKS DJ, GILLETTE J, SCHUBERT M, ORBAN PC, KLEIN R, KRONE W, MULLER-WIELAND D, KAHN CR: Role of brain insulin receptor in control of body weight and reproduction. Science 289: 2122-2125, 2000.

BURTON JM, KIMBALL S, VIETH R, BAR-OR A, DOSCH HM, CHEUNG R, GAGNE D, D'SOUZA C, URSELL M, O'CONNOR P: A phase I/II dose-escalation trial of vitamin D3 and calcium in multiple sclerosis. Neurology 74: 1852-1859, 2010.

CALDER PC: Dietary modification of inflammation with lipids. Proc Nutr Soc 61: 345-358, 2002.

CARABOTTI M, SCIROCCO A, MASELLI MA, SEVERI C: The gut-brain axis: interactions between enteric microbiota, central and enteric nervous systems. Ann Gastroenterol 28: 203-209, 2015.

CHERAYIL GD: Sialic acid and fatty acid concentrations in lymphocytes, red blood cells and plasma from patients with multiple sclerosis. J Neurol Sci 63: 1-10, 1984.

CUNNANE SC, HO SY, DORE-DUFFY P, ELLS KR, HORROBIN DF: Essential fatty acid and lipid profiles in plasma and erythrocytes in patients with multiple sclerosis. Am J Clin Nutr 50: 801-806, 1989.

DANKERS W, COLIN EM, VAN HAMBURG JP, LUBBERTS E: Vitamin D in autoimmunity: molecular mechanisms and therapeutic potential. Front Immunol 7: 697, 2017.

DAS UN: Transforming growth-factor-beta - is it an endogenous cardioprotector. Med Sci Res 21: 373-375, 1993.

DAS UN: Insulin-resistance and hyperinsulinemia - are they secondary to an alteration in the metabolism of essential fatty-acids. Med Sci Res 22: 243-245, 1994.

DAS UN: Beneficial action(S) of eicosapentaenoic acid docosahexaenoic acid and nitric-oxide in systemic LupusErythematosus. Med Sci Res 23: 723-726, 1995. 
DAS UN: Is insulin an antiinflammatory molecule? Nutrition 17: 409-413, $2001 \mathrm{a}$.

DAS UN: Is obesity an inflammatory condition? Nutrition 17: 953-966, $2001 \mathrm{~b}$.

DAS UN: The lipids that matter from infant nutrition to insulin resistance. Prostaglandins Leukot Essent Fatty Acids 67: 1-12, 2002.

DAS UN: A defect in the activity of Delta6 and Delta5 desaturases may be a factor predisposing to the development of insulin resistance syndrome. Prostaglandins Leukot Essent Fatty Acids 72: 343-350, 2005.

DAS UN: A defect in the activity of Delta6 and Delta5 desaturases may be a factor in the initiation and progression of atherosclerosis. Prostaglandins Leukot Essent Fatty Acids 76: 251-268, 2007.

DENDROU CA, FUGGER L, FRIESE MA: Immunopathology of multiple sclerosis. Nat Rev Immunol 15: 545-558, 2015.

DIAZ HEIJTZ R, WANG S, ANUAR F, QIAN Y, BJORKHOLM B, SAMUELSSON A, HIBBERD ML, FORSSBERG H, PETTERSSON S: Normal gut microbiota modulates brain development and behavior. Proc Natl Acad Sci U S A 108: 3047-3052, 2011.

DOS PASSOS GR, SATO DK, BECKER J, FUJIHARA K: Th17 cells pathways in multiple sclerosis and neuromyelitis optica spectrum disorders: pathophysiological and therapeutic implications. Mediators Inflamm 2016: $5314541,2016$.

DWORKIN RH, BATES D, MILLAR JH, PATY DW: Linoleic acid and multiple sclerosis: a reanalysis of three double-blind trials. Neurology 34: 1441-1445, 1984.

ESPARZA ML, SASAKI S, KESTELOOT H: Nutrition, latitude, and multiple sclerosis mortality: an ecologic study. Am J Epidemiol 142: 733-737, 1995.

EVANS C, BELAND SG, KULAGA S, WOLFSON C, KINGWELL E, MARRIOTT J, KOCH M, MAKHANI N, MORROW S, FISK J, DYKEMAN J, JETTE N, PRINGSHEIM T, MARRIE RA: Incidence and prevalence of multiple sclerosis in the Americas: a systematic review. Neuroepidemiology 40: 195-210, 2013.

FAO (Food and Agriculture Organization of the United Nations): Fats and fatty acids in human nutrition - report of an expert consultation. http://www.fao.org/3/a-i1953e.pdf, 2010.

FARINOTTI M, VACCHI L, SIMI S, DI PIETRANTONJ C, BRAIT L, FILIPPINI G: Dietary interventions for multiple sclerosis. Cochrane Database Syst Rev 12: CD004192, 2012.

FERNANDES G, TROYER DA, JOLLY CA: The effects of dietary lipids on gene expression and apoptosis. Proc Nutr Soc 57: 543-550, 1998.

FETTERMAN JW JR, ZDANOWICZ MM: Therapeutic potential of n-3 polyunsaturated fatty acids in disease. Am J Health Syst Pharm 66: 1169-1179, 2009.

GALLAI V, SARCHIELLI P, TREQUATTRINI A, MURASECCO D: Supplementation of polyunsaturated fatty acids in multiple sclerosis. Ital J Neurol Sci 13: 401-407, 1992.

GALLAI V, SARCHIELLI P, TREQUATTRINI A, FRANCESCHINI M, FLORIDI A, FIRENZE C, ALBERTI A, DI BENEDETTO D, STRAGLIOTTO E: Cytokine secretion and eicosanoid production in the peripheral blood mononuclear cells of MS patients undergoing dietary supplementation with n-3 polyunsaturated fatty acids. J Neuroimmunol 56: 143-153, 1995.

GHADIRIAN P, JAIN M, DUCIC S, SHATENSTEIN B, MORISSET R: Nutritional factors in the aetiology of multiple sclerosis: a case-control study in Montreal, Canada. Int J Epidemiol 27: 845-852, 1998.

GONG X, XIE Z, ZUO H: In vivo insulin deficiency as a potential etiology for demyelinating disease. Med Hypotheses 71: 399-403, 2008.

GRYTTEN N, TORKILDSEN O, MYHR KM: Time trends in the incidence and prevalence of multiple sclerosis in Norway during eight decades. Acta Neurol Scand 132: 29-36, 2015.

HARTL C, OBERMEIER V, GERDES LA, BRÜGEL M, VON KRIES R, KÜMPFEL T: Seasonal variations of 25-OH vitamin D serum levels are associated with clinical disease activity in multiple sclerosis patients. $J$ Neurol Sci 375: 160-164, 2017.

HILL JM, LESNIAK MA, PERT CB, ROTH J: Autoradiographic localization of insulin receptors in rat brain: prominence in olfactory and limbic areas. Neuroscience 17: 1127-1138, 1986. 
HOARE S, LITHANDER F, VAN DER MEI I, PONSONBY AL, LUCAS R; AUSIMMUNE INVESTIGATOR G: Higher intake of omega-3 polyunsaturated fatty acids is associated with a decreased risk of a first clinical diagnosis of central nervous system demyelination: results from the Ausimmune Study. Mult Scler 22: 884-892, 2016.

HOLMAN RT, JOHNSON SB, KOKMEN E: Deficiencies of polyunsaturated fatty acids and replacement by nonessential fatty acids in plasma lipids in multiple sclerosis. Proc Natl Acad Sci U S A 86: 4720-4724, 1989.

HONG S, LU Y: Omega-3 fatty acid-derived resolvins and protectins in inflammation resolution and leukocyte functions: targeting novel lipid mediator pathways in mitigation of acute kidney injury. Front Immunol 4: 13, 2013.

HOOPER LV: Bacterial contributions to mammalian gut development. Trends Microbiol 12: 129-134, 2004.

JAMES E, DOBSON R, KUHLE J, BAKER D, GIOVANNONI G, RAMAGOPALAN SV: The effect of vitamin Drelated interventions on multiple sclerosis relapses: a meta-analysis. Mult Scler 19: 1571-1579, 2013.

KAMPMAN MT, STEFFENSEN LH, MELLGREN SI, JØRGENSEN L: Effect of vitamin D3 supplementation on relapses, disease progression, and measures of function in persons with multiple sclerosis: exploratory outcomes from a double-blind randomised controlled trial. Mult Scler 18: 1144-1151, 2012.

KINGWELL E, MARRIOTT JJ, JETTE N, PRINGSHEIM T, MAKHANI N, MORROW SA, FISK JD, EVANS C, BELAND SG, KULAGA S, DYKEMAN J, WOLFSON C, KOCH MW, MARRIE RA: Incidence and prevalence of multiple sclerosis in Europe: a systematic review. BMC Neurol 13: 128, 2013.

KONG-GONZALEZ M, PEREZ-CORTEZ JG, HERNANDEZ-GIRON C, MACIAS-MORALES N, FLORESALDANA M: Polyunsaturated fatty acids for multiple sclerosis treatment: scientific evidence (in Spanish). Medwave 15: e6062, 2015.

KUBOKI K, JIANG ZY, TAKAHARA N, HA SW, IGARASHI M, YAMAUCHI T, FEENER EP, HERBERT TP, RHODES CJ, KING GL: Regulation of endothelial constitutive nitric oxide synthase gene expression in endothelial cells and in vivo: a specific vascular action of insulin. Circulation 101: 676-681, 2000.

KUMAR GS, DAS UN: Effect of prostaglandins and their precursors on the proliferation of human lymphocytes and their secretion of tumor necrosis factor and various interleukins. Prostaglandins Leukot Essent Fatty Acids 50: 331-334, 1994.

KUMAR GS, DAS UN, KUMAR KV, MADHAVI N, DAS NP, TAN BKH: Effect of N-6 and N-3 fatty-acids on the proliferation of human-lymphocytes and their secretion of TNF-alpha and IL-2 in vitro. Nutr Res 12: 815-823, 1992.

LAURITZEN I, BLONDEAU N, HEURTEAUX C, WIDMANN C, ROMEY G, LAZDUNSKI M: Polyunsaturated fatty acids are potent neuroprotectors. EMBO J 19: 1784-1793, 2000.

LEE YK, MENEZES JS, UMESAKI Y, MAZMANIAN SK: Proinflammatory T-cell responses to gut microbiota promote experimental autoimmune encephalomyelitis. Proc Natl Acad Sci U S A 108 (Suppl 1): 4615-4622, 2011.

LEONG EM, SEMPLE SJ, ANGLEY M, SIEBERT W, PETKOV J, MCKINNON RA: Complementary and alternative medicines and dietary interventions in multiple sclerosis: what is being used in South Australia and why? Complement Ther Med 17: 216-223, 2009.

LIM SY, SUZUKI H: Effect of dietary docosahexaenoic acid and phosphatidylcholine on maze behavior and fatty acid composition of plasma and brain lipids in mice. Int J Vitam Nutr Res 70: 251-259, 2000.

LOCK C, HERMANS G, PEDOTTI R, BRENDOLAN A, SCHADT E, GARREN H, LANGER-GOULD A, STROBER S, CANNELLA B, ALLARD J, KLONOWSKI P, AUSTIN A, LAD N, KAMINSKI N, GALLI SJ, OKSENBERG JR, RAINE CS, HELLER R, STEINMAN L: Gene-microarray analysis of multiple sclerosis lesions yields new targets validated in autoimmune encephalomyelitis. Nat Med 8: 500-508, 2002.

MARCK CH, NEATE SL, TAYLOR KL, WEILAND TJ, JELINEK GA: Prevalence of comorbidities, overweight and obesity in an international sample of people with multiple sclerosis and associations with modifiable lifestyle factors. PLoS One 11: e0148573, 2016.

MARRACCI GH, JONES RE, MCKEON GP, BOURDETTE DN: Alpha lipoic acid inhibits T cell migration into the spinal cord and suppresses and treats experimental autoimmune encephalomyelitis. $J$ Neuroimmunol 131: 104-114, 2002. 
MARRACCI GH, MCKEON GP, MARQUARDT WE, WINTER RW, RISCOE MK, BOURDETTE DN: Alpha lipoic acid inhibits human T-cell migration: implications for multiple sclerosis. J Neurosci Res 78: 362-370, 2004.

MARRIE RA, HADJIMICHAEL O, VOLLMER T: Predictors of alternative medicine use by multiple sclerosis patients. Mult Scler 9: 461-466, 2003.

MASULLO L, PAPAS MA, COTUGNA N, BAKER S, MAHONEY L, TRABULSI J: Complementary and alternative medicine use and nutrient intake among individuals with multiple sclerosis in the United States. J Community Health 40: 153-160, 2015.

MAYER EA, TILLISCH K, GUPTA A: Gut/brain axis and the microbiota. $J$ Clin Invest 125: 926-938, 2015.

MIYAKE S, KIM S, SUDA W, OSHIMA K, NAKAMURA M, MATSUOKA T, CHIHARA N, TOMITA A, SATO W, KIM SW, MORITA H, HATTORI M, YAMAMURA T: Dysbiosis in the gut microbiota of patients with multiple sclerosis, with a striking depletion of species belonging to Clostridia XIVa and IV clusters. PLoS One 10: $\mathrm{e} 0137429,2015$.

MORINI M, ROCCATAGLIATA L, DELL'EVA R, PEDEMONTE E, FURLAN R, MINGHELLI S, GIUNTI D, PFEFFER U, MARCHESE M, NOONAN D, MANCARDI G, ALBINI A, UCCELLI A: Alpha-lipoic acid is effective in prevention and treatment of experimental autoimmune encephalomyelitis. $J$ Neuroimmunol 148: 146-153, 2004.

NAYAK S, MATHEIS RJ, SCHOENBERGER NE, SHIFLETT SC: Use of unconventional therapies by individuals with multiple sclerosis. Clin Rehabil 17: 181-191, 2003.

NEWMAN MJ: Inhibition of carcinoma and melanoma cell growth by type 1 transforming growth factor beta is dependent on the presence of polyunsaturated fatty acids. Proc Natl Acad Sci U S A 87: 5543-5547, 1990.

NIGHTINGALE S, WOO E, SMITH AD, FRENCH JM, GALE MM, SINCLAIR HM, BATES D, SHAW DA: Red blood cell and adipose tissue fatty acids in mild inactive multiple sclerosis. Acta Neurol Scand 82: 43-50, 1990.

NORDVIK I, MYHR KM, NYLAND H, BJERVE KS: Effect of dietary advice and n-3 supplementation in newly diagnosed MS patients. Acta Neurol Scand 102: 143-149, 2000.

OCHOA-REPARAZ J, MIELCARZ DW, DITRIO LE, BURROUGHS AR, FOUREAU DM, HAQUE-BEGUM S, KASPER LH: Role of gut commensal microflora in the development of experimental autoimmune encephalomyelitis. J Immunol 183: 6041-6050, 2009.

PAGE SA, VERHOEF MJ, STEBBINS RA, METZ LM, LEVY JC: The use of complementary and alternative therapies by people with multiple sclerosis. Chronic Dis Can 24: 75-79, 2003.

PENESOVA A, VLCEK M, IMRICH R, VERNEROVA L, MARKO A, MESKOVA M, GRUNNEROVA L, TURCANI P, JEZOVA D, KOLLAR B: Hyperinsulinemia in newly diagnosed patients with multiple sclerosis. Metab Brain Dis 30: 895-901, 2015.

PETRA AI, PANAGIOTIDOU S, HATZIAGELAKI E, STEWART JM, CONTI P, THEOHARIDES TC: Gutmicrobiota-brain axis and its effect on neuropsychiatric disorders with suspected immune dysregulation. Clin Ther 37: 984-995, 2015.

PIERROT-DESEILLIGNY C, SOUBERBIELLE JC: Vitamin D and multiple sclerosis: an update. Mult Scler Relat Disord 14: 35-45, 2017.

PRIEBE MG, WANG H, WEENING D, SCHEPERS M, PRESTON T, VONK RJ: Factors related to colonic fermentation of nondigestible carbohydrates of a previous evening meal increase tissue glucose uptake and moderate glucose-associated inflammation. Am J Clin Nutr 91: 90-97, 2010.

RAMIREZ-RAMIREZ V, MACIAS-ISLAS MA, ORTIZ GG, PACHECO-MOISES F, TORRES-SANCHEZ ED, SORTO-GOMEZ TE, CRUZ-RAMOS JA, OROZCO-AVINA G, CELIS DE LA ROSA AJ: Efficacy of fish oil on serum of TNF alpha, IL-1 beta, and IL-6 oxidative stress markers in multiple sclerosis treated with interferon beta-1b. Oxid Med Cell Longev 2013: 709493, 2013.

REZAPOUR-FIROUZI S, AREFHOSSEINI SR, EBRAHIMI-MAMAGHANI M, BARADARAN B, SADEGHIHOKMABAD E, MOSTAFAEI S, TORBATI M, CHEHREH M: Alteration of delta-6-desaturase (FADS2), secretory phospholipase-A2 (sPLA2) enzymes by Hot-nature diet with co-supplemented hemp seed, evening primrose oils intervention in multiple sclerosis patients. Complement Ther Med 23: 652-657, 2015. 
RICCIO P, ROSSANO R, LAROCCA M, TROTTA V, MENNELLA I, VITAGLIONE P, ETTORRE M, GRAVERINI A, DE SANTIS A, DI MONTE E, CONIGLIO MG: Anti-inflammatory nutritional intervention in patients with relapsing-remitting and primary-progressive multiple sclerosis: a pilot study. Exp Biol Med (Maywood) 241: 620-635, 2016.

RIEMANN-LORENZ K, EILERS M, VON GELDERN G, SCHULZ KH, KOPKE S, HEESEN C: Dietary interventions in multiple sclerosis: development and pilot-testing of an Evidence Based Patient Education Program. PLoS One 11: e0165246, 2016.

ROBERTSON MD, BICKERTON AS, DENNIS AL, VIDAL H, FRAYN KN: Insulin-sensitizing effects of dietary resistant starch and effects on skeletal muscle and adipose tissue metabolism. Am J Clin Nutr 82: 559-567, 2005.

RULIFSON EJ, KIM SK, NUSSE R: Ablation of insulin-producing neurons in flies: growth and diabetic phenotypes. Science 296: 1118-1120, 2002.

SALA-VILA A, GUASCH-FERRE M, HU FB, SANCHEZ-TAINTA A, BULLO M, SERRA-MIR M, LOPEZSABATER C, SORLI JV, AROS F, FIOL M, MUNOZ MA, SERRA-MAJEM L, MARTINEZ JA, CORELLA D, FITO M, SALAS-SALVADO J, MARTINEZ-GONZALEZ MA, ESTRUCH R, ROS E; PREDIMED INVESTIGATORS: Dietary alpha-linolenic acid, marine omega-3 fatty acids, and mortality in a population with high fish consumption: findings from the PREvencion con DIeta MEDiterranea (PREDIMED) Study. $J$ Am Heart Assoc 5: e002543, 2016.

SALINTHONE S, YADAV V, SCHILLACE RV, BOURDETTE DN, CARR DW: Lipoic acid attenuates inflammation via cAMP and protein kinase A signaling. PLoS One 5: e13058, 2010.

SCHREIBELT G, MUSTERS RJ, REIJERKERK A, DE GROOT LR, VAN DER POL SM, HENDRIKX EM, DOPP ED, DIJKSTRA CD, DRUKARCH B, DE VRIES HE: Lipoic acid affects cellular migration into the central nervous system and stabilizes blood-brain barrier integrity. J Immunol 177: 2630-2637, 2006.

SCHWARTZ CE, LAITIN E, BROTMAN S, LAROCCA N: Utilization of unconventional treatments by persons with MS: is it alternative or complementary? Neurology 52: 626-629, 1999.

SCHWARZ S, KNORR C, GEIGER H, FLACHENECKER P: Complementary and alternative medicine for multiple sclerosis. Mult Scler 14: 1113-1119, 2008.

SERHAN CN, DALLI J, COLAS RA, WINKLER JW, CHIANG N: Protectins and maresins: new pro-resolving families of mediators in acute inflammation and resolution bioactive metabolome. Biochim Biophys Acta 1851: 397-413, 2015.

SHERRY CL, KIM SS, DILGER RN, BAUER LL, MOON ML, TAPPING RI, FAHEY GC JR, TAPPENDEN KA, FREUND GG: Sickness behavior induced by endotoxin can be mitigated by the dietary soluble fiber, pectin, through up-regulation of IL-4 and Th2 polarization. Brain Behav Immun 24: 631-640, 2010.

SHINTO L, MARRACCI G, BALDAUF-WAGNER S, STREHLOW A, YADAV V, STUBER L, BOURDETTE D: Omega-3 fatty acid supplementation decreases matrix metalloproteinase-9 production in relapsing-remitting multiple sclerosis. Prostaglandins Leukot Essent Fatty Acids 80: 131-136, 2009.

SOILU-HÄNNINEN M, AIVO J, LINDSTRÖM BM, ELOVAARA I, SUMELAHTI ML, FÄRKKILÄ M, TIENARI P, ATULA S, SARASOJA T, HERRALA L, KESKINARKAUS I, KRUGER J, KALLIO T, ROCCA MA, FILIPPI M: A randomised, double blind, placebo controlled trial with vitamin D3 as an add on treatment to interferon $\beta-1 \mathrm{~b}$ in patients with multiple sclerosis. J Neurol Neurosurg Psychiatry 83: 565-571, 2012.

STORONI M, PLANT GT: The therapeutic potential of the ketogenic diet in treating progressive multiple sclerosis. Mult Scler Int 2015: 681289, 2015.

STUIFBERGEN AK, HARRISON TC: Complementary and alternative therapy use in persons with multiple sclerosis. Rehabil Nurs 28: 141-147, 158, 2003.

SUN Q, LI J, GAO F: New insights into insulin: the anti-inflammatory effect and its clinical relevance. World $J$ Diabetes 5: 89-96, 2014.

SWANK RL: Multiple sclerosis; a correlation of its incidence with dietary fat. Am J Med Sci 220: 421-430, 1950.

SWANK RL, DUGAN BB: Effect of low saturated fat diet in early and late cases of multiple sclerosis. Lancet 336: 37-39, 1990. 
SWANK RL, GOODWIN J: Review of MS patient survival on a Swank low saturated fat diet. Nutrition 19: 161-162, 2003a.

SWANK RL, GOODWIN JW: How saturated fats may be a causative factor in multiple sclerosis and other diseases. Nutrition 19: 478, 2003b.

TARINI J, WOLEVER TM: The fermentable fibre inulin increases postprandial serum short-chain fatty acids and reduces free-fatty acids and ghrelin in healthy subjects. Appl Physiol Nutr Metab 35: 9-16, 2010.

TILLISCH K: The effects of gut microbiota on CNS function in humans. Gut Microbes 5: 404-410, 2014.

UMBRELLO G, ESPOSITO S: Microbiota and neurologic diseases: potential effects of probiotics. $J$ Transl Med 14: 298, 2016.

WEINSTOCK-GUTTMAN B, BAIER M, PARK Y, FEICHTER J, LEE-KWEN P, GALLAGHER E, VENKATRAMAN J, MEKSAWAN K, DEINEHERT S, PENDERGAST D, AWAD AB, RAMANATHAN M, MUNSCHAUER F, RUDICK R: Low fat dietary intervention with omega-3 fatty acid supplementation in multiple sclerosis patients. Prostaglandins Leukot Essent Fatty Acids 73: 397-404, 2005.

WERGELAND S, TORKILDSEN O, BO L, MYHR KM: Polyunsaturated fatty acids in multiple sclerosis therapy. Acta Neurol Scand Suppl 126: 70-75, 2012.

WILCZYNSKA-KWIATEK A, DE MEESTER F, SINGH RB, LAPINSKI L: Western diet and behavior: the columbus concept. In: Modern Dietary Fat Intakes in Disease Promotion. DE MEESTER F, ZIBADI S, WATSON RR (eds), Humana Press, c/o Springer Science+Business Media, New York, USA, 2010, pp 3-29.

WILSON R, TOCHER DR: Lipid and fatty acid composition is altered in plaque tissue from multiple sclerosis brain compared with normal brain white matter. Lipids 26: 9-15, 1991.

WOLEVER TM, CHIASSON JL: Acarbose raises serum butyrate in human subjects with impaired glucose tolerance. Br J Nutr 84: 57-61, 2000.

WONG EK JR, ENOMOTO H, LEOPOLD IH, WILLIAMS JL, KLADDE L, HOLLANDER DH: Intestinal absorption of dietary fat in patients with multiple sclerosis. Metab Pediatr Syst Ophthalmol (1985) 16: 39-42, 1993.

WU H, ZHAO M, YOSHIMURA A, CHANG C, LU Q: Critical link between epigenetics and transcription factors in the induction of autoimmunity: a comprehensive review. Clin Rev Allergy Immunol 50: 333-344, 2016.

XU ZZ, ZHANG L, LIU T, PARK JY, BERTA T, YANG R, SERHAN CN, JI RR: Resolvins RvE1 and RvD1 attenuate inflammatory pain via central and peripheral actions. Nat Med 16: 592-597, 2010.

YADAV V, SHINTO L, MORRIS C, SENDERS A, BELDAUF-WAGNER S, BOURDETTE D: Use and self-reported benefit of complementary and alternative medicine among multiple sclerosis patients. Int J MS Care 8: 5-10, 2006.

YADAV V, MARRACCI GH, MUNAR MY, CHERALA G, STUBER LE, ALVAREZ L, SHINTO L, KOOP DR, BOURDETTE DN: Pharmacokinetic study of lipoic acid in multiple sclerosis: comparing mice and human pharmacokinetic parameters. Mult Scler 16: 387-397, 2010a.

YADAV V, SHINTO L, BOURDETTE D: Complementary and alternative medicine for the treatment of multiple sclerosis. Expert Rev Clin Immunol 6: 381-395, 2010 b.

YOKOTE H, MIYAKE S, CROXFORD JL, OKI S, MIZUSAWA H, YAMAMURA T: NKT cell-dependent amelioration of a mouse model of multiple sclerosis by altering gut flora. Am J Pathol 173: 1714-1723, 2008.

ZHANG SM, HERNAN MA, OLEK MJ, SPIEGELMAN D, WILLETT WC, ASCHERIO A: Intakes of carotenoids, vitamin C, and vitamin E and MS risk among two large cohorts of women. Neurology 57: 75-80, 2001.

ZHORNITSKY S, MCKAY KA, METZ LM, TEUNISSEN CE, RANGACHARI M: Cholesterol and markers of cholesterol turnover in multiple sclerosis: relationship with disease outcomes. Mult Scler Relat Disord 5: 53-65, 2016.

ZIEGLER D, RELJANOVIC M, MEHNERT H, GRIES FA: Alpha-lipoic acid in the treatment of diabetic polyneuropathy in Germany: current evidence from clinical trials. Exp Clin Endocrinol Diabetes 107: 421-430, 1999. 